University at Buffalo School of Law

Digital Commons @ University at Buffalo School of Law

2016

\title{
On the Place of Judge-Made Law in a Government of Laws
}

Matthew J. Steilen

University at Buffalo School of Law

Follow this and additional works at: https://digitalcommons.law.buffalo.edu/journal_articles

Part of the Common Law Commons, Judges Commons, and the Rule of Law Commons

\section{Recommended Citation}

Matthew J. Steilen, On the Place of Judge-Made Law in a Government of Laws, 3 Critical Analysis L. 243 (2016).

Available at: https://digitalcommons.law.buffalo.edu/journal_articles/120

\section{(c) (i)}

This work is licensed under a Creative Commons Attribution 3.0 Unported License.

This Article is brought to you for free and open access by the Faculty Scholarship at Digital Commons @ University at Buffalo School of Law. It has been accepted for inclusion in Journal Articles by an authorized administrator of Digital Commons @ University at Buffalo School of Law. For more information, please contact lawscholar@buffalo.edu. 


\title{
On the Place of Judge-Made Law in a Government of Laws
}

\section{Matthew Steilen*}

\begin{abstract}
This essay explores a constitutional account of the elevation of the judiciary in American states following the Revolution. The core of the account is a connection between two fundamental concepts in Anglo-American constitutional thinking, discretion and a government of laws. In the periods examined here, arbitrary discretion tended to be associated with alien power and heteronomy, while bounded discretion was associated with self-rule. The formal, solemn, forensic, and public character of proceedings in courts of law suggested to some that judge-made law (a product of judicial discretion under these proceedings) did not express simply the will of the judge or the ruler, but the law of the community. This view may explain why the new American republican regimes elevated their judiciaries, insulating them from political control, while at the same time reforming judicial procedures and trimming traditional jurisdictions to exclude matters that invited judges to exercise an arbitrary discretion.
\end{abstract}

\section{Introduction}

The decades following the American Revolution brought dramatic changes for courts of law. ${ }^{1}$ From a constitutional perspective, perhaps the most surprising aspect of this development is the elevation of the judiciary, whose office was made independent of the legislature by constitutions in a number of states, and by the federal Constitution as well. ${ }^{2}$ Why a transition from limited monarchy to republic should have resulted in a constitutional promotion for judges is puzzling. "Republic" does not exclude, by its meaning, forms of government with an independent executive (in whose constitutional functions the judiciary might be thought to share), but in the eighteenth-century British Empire, the term was usually associated with the elevation of popular bodies like the assembly or the jury. ${ }^{3}$ Why should judges have increased their constitutional station in the new American republics? And why should they have sustained this station in the decades that followed, given the rapid democratization of American political culture?

\footnotetext{
* Associate Professor, University at Buffalo School of Law, State University of New York. This essay derives from remarks given in a Stead Seminar at the University of Baltimore School of Law in March 2015. I want to thank Jim Maxeiner and the seminar participants, as well as Fred Konefsky, Jack Schlegel and Norm Spaulding.

${ }^{1}$ Gordon S. Wood, The Creation of the American Republic, 1776-1787, at 453-63 (1969).

2 Donald S. Lutz, The Origins of American Constitutionalism 104, 109 (1988); Scott Douglas Gerber, A Distinct Judicial Power: The Origins of an Independent Judiciary, 1606-1787, at 328-29 (2011).

${ }^{3}$ Eric Nelson, The Royalist Revolution: Monarchy and the American Founding 116-17 (2014); Philip Pettit, Two Republican Traditions, in Republican Democracy: Liberty, Law and Politics 169, 186-87 (Andreas Niederberger \& Philipp Schink eds., 2013).
}

ISSN 2291-9732 
My aim here is to contribute to a constitutional answer to these questions by sketching some connections between the judicial office and two fundamental concepts of Anglo-American constitutionalism: a government of laws and arbitrary discretion. ${ }^{4}$ We are familiar with arguments that the judiciary could preserve a government of laws by voiding arbitrary acts of the popular assembly. ${ }^{5}$ But "judicial review" did not exhaust the constitutional role envisioned for the judiciary in the new regimes. I want to explore the proposition that the judiciary also preserved a government of laws by declaring or promulgating law-what we now call "judge-made law." In many ways, this proposition is far more surprising, and the power granted to the judiciary greater than that of judicial review.

At the center of the constitutional account I shall be exploring are a set of attitudes about procedure. The men who held these attitudes tended to regard judicial procedure as in some way transforming judge-made law into an expression of the law of the community. By "proceduralizing" the discretion implied in the administration of government, judge-made law became an expression of the social content of rights, rather than an arbitrary and alien executive discretion. ${ }^{6}$ To the extent that judge-made law could be characterized as the law of the community, or an exposition of the principles of the law of the community, there was, in turn, a persuasive constitutional argument for elevating the station of the judiciary. As we will see, however, the argument was an unstable one, and American writers contested the place of judge-made law under their new constitutions. Where judge-made law looked like an exercise of arbitrary discretion, the policy of judicial doctrine appeared partisan, and an independent judiciary became a target of criticism. This was the heart of the jurisprudential objection to a federal common law of crimes.

In working through these ideas below, I make use of a lengthy comparison to the early common law. The point of the comparison is not to attempt a transplant of medieval institutions into eighteenth-century America, or to discover proto-democratic ones in medieval England. An understanding of how the king's courts transformed royal discretion into a law for the realm is nonetheless useful in forming a constitutional view of American judicial power, primarily for suggesting distinctions. In light of the comparison, we can see the controversy over a common law of crimes as concerning, at least in part, those areas of common-law jurisdiction whose exercise necessitated a broad grant of discretion to the judiciary. And we can see defenses of judge-made law advanced in the wake of the controversy as centered on ways in which common-law procedures limited judicial discretion and thereby connected its exercise to the sense of the community.

\footnotetext{
${ }^{4}$ John Phillip Reid, In Legitimate Stirps: The Concept of "Arbitrary," the Supremacy of Parliament, and the Coming of the American Revolution, 5 Hofstra L. Rev. 459, 463-64 (1977). On constitutional explanation, see Jack P. Greene, The Constitutional Origins of the American Revolution ix-xxiv (2011).

${ }^{5}$ Larry Kramer, The People Themselves: Popular Constitutionalism and Judicial Review 28 (2004); Philip Hamburger, Law and Judicial Duty 456 n.163 (2008).

6 William J. Novak, Intellectual Origins of the State Police Power: The Common Law Vision of a WellRegulated Society 29-58, 88-90, 92 (1989); Kunal M. Parker, Common Law, History, and Democracy in America, 1790-1900, at 87-88 (2011); Reid, supra note 4, at 463-64.
} 


\section{A Government of Laws and Judge-Made Law}

"Government of laws" was a common expression in the eighteenth century. ${ }^{7}$ Like "rule of law," "government of laws" was ambiguous. It signaled, first, that government would act by known and fixed rules. ${ }^{8}$ In this sense, government of laws lay close to the heart of social contract theory. Indeed, government by "establish'd, settled, known Law" was the first purpose of the Lockean social contract, and essential to the adequate protection of property." "Government of laws" signaled a second idea as well. It was "free government," or government consistent with the freedom of the governed, and as such advanced the common good rather than private interest. For British Americans of the late eighteenth century, probably the leading development of this idea occurred in James Harrington's work, The Commonwealth of Oceana. ${ }^{10}$ Harrington argued that a commonwealth or republic was a "government de jure" because of its institutional structure, which prevented the king and aristocracy from using government to advance their interests at the expense of the people. The commonwealth did this by dividing legislative power and placing it in multiple hands. Free government was thus identifiable by the existence of checks on power, which operated to prevent the promotion of private interests. Writing over one hundred years later, John Adams helped himself to a significant portion of Harrington's argument in his defense of bicameralism in American legislative bodies. ${ }^{11}$

As a first approximation, we can already sketch a connection between both senses of "government of laws" and judge-made law. Americans of the late eighteenth century were familiar with the idea that judges might make substantive bodies of law. The outstanding example of such a judge is undoubtedly Lord Mansfield, who is credited with developing a modern law of contract, and complaints about Mansfield sound in the precise register relevant here. Thomas Jefferson remarked that "[t]he object of former judges has been to render the law more and more certain," while Mansfield's object was "to render it more incertain under pretence of rendering it more reasonable." "Such a view, he continued, had no place "in a free country wherein every power is dangerous which is not bound up by general rules." 13 The practice of reforming the law in the context of a judicial case rendered the law perpetually uncertain, and thus was inconsistent with a government of laws.

\footnotetext{
7 The dominance of "rule of law," which is more common today, is a result of the influence of Dicey's treatise on English constitutional law. Tom Bingham, The Rule of Law 3 (2010).

${ }^{8}$ John Gray, The Right of the British Legislature to Tax the American Colonies Vindicated 98 (2d ed. 1775); Forrest McDonald, Novus Ordo Seclorum: The Intellectual Origins of the Constitution 9 (1985).

9 John Locke, The Second Treatise of Government \ 124 (1689).

10 James Harrington, The Commonwealth of Oceana 8, 19-25 (J.G.A. Pocock ed., 1992) (1656).

111 John Adams, A Defence of the Constitutions of Government of the United States 121-23, 134-41 (1787).

12 Letter from Thomas Jefferson to Philip Mazzei (Nov. 1785), in 9 The Papers of Thomas Jefferson 67, 71 (Julian P. Boyd ed., 1954).

${ }^{13} \mathrm{Id}$.
} 
We can sketch a similar argument using "government of laws" in its second sense, government on the basis of the common good. The waypoint is the doctrine of separation of powers, to which the leading American conservatives gave a central place in their constitutional thinking in the 1780s. A "free republic," argued John Adams, required not simply that there be "equal laws, made with common consent," but that those laws be made "for the general interest, or the public good." 14 The desideratum necessitated a bicameral assembly. If the republic had only "a single assembly," it would quickly "divide into two or three parties," each of which would seek to advance its own private interests. The solution was to divide legislative power between a senate and a house of representatives, giving to the senate a power to propose laws, and to the house a power to approve the senate's proposals. Such a division would prevent the legislative power from being used to promote the private interests of the dominant faction. Separating judicial power from legislative and executive power served the same ends. Thus, Article XXX of the Massachusetts Constitution of 1780, of which Adams was the principal draftsman, provided that the judicial branch "shall never exercise the legislative and executive powers, or either of them; to the end it may be a government of laws, and not of men." "15 A judiciary that adjudicated cases and made law could act on individuals without legislative interference, at least in the first instance, and would eventually come to serve the narrow interests of judges or the factions with which they associated. According to Adams, then, it was juries, not judges, that ought to decide the law that governed a case. ${ }^{16}$

In both senses, then, a "government of laws" looks to be inconsistent with judgemade law. We can paraphrase these arguments as follows:
P1. A government of laws is a government in which (action follows known, fixed rules) (the common good, rather than private interest, controls).
P2. When a judge makes law, he (does not act based on known, fixed rules) (he can legislate on the basis of private interest).
C. A government of laws is one in which no judge makes law.

The paraphrase is really an argument schema, rather than a determinate argument. Whether its instances are sound depends a great deal on how we develop the ideas in the parentheticals, which I have so far only briefly sketched. My interest here is in exploring one such development, based on the first sense of "government of laws," government by known and fixed rules. As I mentioned above, one might look to the theory of the social contract to fill out this idea. Some period texts suggest, however, a slightly different direction. According to these texts, known and fixed rules are desirable because they control discretion.

For example, according to Jonathan Mayhew, a leading American Congregationalist minister of the mid-eighteenth century, "in all free constitutions of government, law, and

\footnotetext{
14 Adams, supra note 11 , at 123.

15 Art. XXX, Massachusetts Constitution of 1780; Gerber, supra note 2, at 87.

16 Shannon C. Stimson, The American Revolution in the Law: Anglo-American Jurisprudence Before John Marshall 71-82 (1990).
} 
not will, is the measure of the executive Magistrate's power." ${ }^{\prime 17}$ The idea here is not only that the executive is powerless to act unless the law authorizes him to do so, say, because a crime has been committed and he must enforce the law. The idea is also that where the executive acts, he must act according to certain procedures described by law. A government of law was a government of procedures, and more specifically, a government whose executive acted through settled procedures. As John Phillip Reid has explained it, "[T]he concept of the rule of law defined government as . . the circumscribing of power by 'some settled Rule or Order of Operation." "18 Failure to observe procedure was a violation of the law, and where an individual was injured as a result, a government of laws should give that individual a cause of action against the offending magistrate-however high his station might be. ${ }^{19}$ The opposite of a government of laws in this sense was arbitrary government. Officers in such a government enjoyed arbitrary discretion, insofar as they were not required to follow a settled, customary procedure, laid out in law, in exercising their powers. ${ }^{20}$

My contention is that once we put procedure and discretion at the center of the picture, the place of judge-made law in a government of laws will look very different, and that this is the seed of a persuasive constitutional argument to elevate the station of the judiciary. To see these relationships clearly, however, I think it is useful to step outside the perspective of the late eighteenth-century, where institutional changes in American courts of law obscure the matter. We should begin, instead, with the period in which the common law originated, where the relationship between procedure and magisterial discretion is somewhat easier to discern.

\section{Early English Common Law}

"Medieval political thought," wrote Ewart Lewis, "was a response to a special historical situation." 21 Its aim was to justify an expansion of royal power into a society whose political structure was provided by feudalism and the church. In England, the kingship of Stephen of Blois lapsed into anarchy in part because of the feudal or "contractual" character it assumed, which encouraged barons dissatisfied with Stephen's rule to assert their independence. ${ }^{22}$ Under Henry II, who followed Stephen, we see the deliberate extension

\footnotetext{
${ }^{17}$ Jonathan Mayhew, A Sermon Preach'd in the Audience of His Excellency William Shirley, Esq. 24 (1754).

${ }^{18}$ John Phillip Reid, Constitutional History of the American Revolution 21-22 (abr. ed. 1995) (emphasis added).

${ }^{19}$ Chief Justice Marshall addressed the President when he remarked that "[t]he government of the United States has been emphatically termed a government of laws, and not of men. It will certainly cease to deserve this high appellation, if the laws furnish no remedy for the violation of a vested legal right." Marbury v. Madison, 5 U.S. (1 Cranch) 137, 163 (1803) (emphasis added).

${ }^{20}$ Petition of the Stamp Act Congress, in Principles and Acts of the Revolution in America 164 (Hesekiah Niles ed., 1876); Memento to Americans (March 1776), in id. at 220 ("Remember their arbitrary admiralty courts.").

${ }^{21}$ Ewart Lewis, The Contribution of Medieval Thought to the American Political Tradition, 50 Am. Pol. Sci. Rev. 462, 462 (1956).

${ }^{22}$ G.O. Sayles, The Medieval Foundations of England 313, 317, 322-23 (1948).
} 
of the instruments of royal justice beyond their traditional scope (matters involving great men and the king's tenants-in-chief), in order that the king might address violent dispossessions of land and serious crime. ${ }^{23}$ Stephen's anarchy had to be undone, and it was undone by a "new" form of monarchy, which, traditionally, we have credited with creating the common law. ${ }^{24}$ The ministers who sought to explain and rationalize practices before the king's justices naturally availed themselves of Roman jurisprudence and law, whose study was then flourishing on the continent. ${ }^{25}$ Thus we have the first great English law-books, "Glanvill" and "Bracton." 26 The difficulty faced by the authors of both books was how to situate Roman views that emphasized imperial will and legislation within a feudal tradition in which customary law played a central role. ${ }^{27}$

There is no "theory" of kingship that comes out of Glanvill and Bracton, but both texts evidence what one recent commentator has called "monarchist presuppositions.",28 We should not be surprised if some of what Bracton writes strengthens the hand of the king at the expense of the barons. The king was to enjoy a monopoly on coercive power, and he could not alienate this power to the barons. The king had no peer or superior. In administering his government, the acts of the king were not challengeable in any royal forum. In this sense, administration was a matter of royal discretion. ${ }^{29}$ Professor Lewis saw in these developments "an increasingly clear perception that the government of laws cannot eliminate the government of man; that government by its very nature includes large areas of discretion which must be areas of decisive authority." ${ }^{30}$ In part this lesson was drawn from Stephen's anarchy, and in Bracton's case more immediately from the "Barons' Wars" of the thirteenth century. Yet it was not the whole of the story. Where private rights were affected, executive discretion was limited—not by impenetrable legal boundaries, but by procedures. The great men of the kingdom were protected by chapter 39 of the 1215 Magna Carta, which required the king to obtain a conviction in a suitable forum

23 John Hudson, The Formation of the English Common Law: Law and Society in England from the Norman Conquest to Magna Carta 118-22 (1996).

24 This is Maitland's basic thesis. 1 Frederick Pollock \& Frederic William Maitland, The History of English Law Before the Time of Edward I, at 136-38 (2d ed. 1898).

${ }^{25}$ For a recent study of the efforts to Anglicize possession and property (both Roman legal concepts), see Thomas J. McSweeney, Property Before Property: Romanizing the English Law of Land, 60 Buff. L. Rev. 1139, 1157-59, 1166, 1173-74 (2012).

261 Bracton on the Laws and Customs of England xxxii-xxxix (Samuel Thorne trans., 1968); The Treatise on the Laws and Customs of the Realm of England Commonly Called Glanvill xv-xviii, xxxvi-xl (C.D.G. Hall ed., 1965).

27 Kenneth Pennington, Law, Legislation and Government, 1150-1300, in The Cambridge History of Medieval Political Thought c. 350-c. 1450, at 430 (J.H. Burns ed., 1988) [hereinafter Cambridge History].

${ }^{28}$ Alan Cromartie, The Constitutionalist Revolution: An Essay on the History of England, 1450-1642, at 13 (2006).

29 Brian Tierney, Bracton on Government, 38 Speculum 295, 309 (1963); Charles Howard McIlwain, Constitutionalism Ancient and Modern 79-80, 88 (1940). Tierney modifies Mcllwain but preserves the basic distinction I am interested in.

${ }^{30}$ Lewis, supra note 21, at 464. 
before seizing their persons or property. ${ }^{31}$ And if the king needed a grant of supply (taxation) to defend the kingdom, he must present such a claim and obtain the consent of commons, magnates and prelates, in parliament assembled, at least by the fourteenth century. ${ }^{32}$ With respect to this last example, the term "consent" should not be misunderstood. ${ }^{33}$ What was called for was not the consent of the modern legislator, who might withhold his approval (at least when he enjoys party support), but something like the "consent" of the litigant, who advises the judge on how to resolve his case (the judge takes his arguments "under advisement"), and then accepts her decision, whatever it is, as long as that decision is lawfully made, that is, as long as the judgment is valid. The litigant may disagree with the decision, but his consent in this sense (his "vote") is not required and not expected.

The point here is not just that procedures slowed down the king, or that they discouraged unilateral action, although it seems natural to assume that they had these effects. For reasons I do not quite understand, formal procedure also tended to be accompanied by an understanding that an institution had representative authority. This was clearly true later of the "high court of parliament," but it was also true of some of the earlier royal courts as well, especially common pleas and the king's bench, but also their predecessors "the bench," coram rege, and even the general eyre. The acts of these courts belonged to the realm in a way that summary administrative decisions did not.

Let us take a moment to examine the early common law, here understood as process by writ original, resulting, in some cases, in proceedings before the king's justices. The expansion of these procedures and the growth of the royal courts were administrative innovations undertaken by the king with the aid of his council, and, in a few cases, with the assent of the great men of the realm. These innovations built on existing institutions, practices and understandings, but they were innovations nonetheless, for at the very least they routinized and systematized what had previously been ad hoc. What is distinctive about the common law is the way in which these innovations, which in some cases extended royal prerogatives, ${ }^{34}$ became quickly encrusted with routine and formality, which themselves in turn became objects of popular expectation. The explanation for this may be that these administrative innovations bottomed, in some way, on custom or existing practices. ${ }^{35}$ But whether or not that is the case, once procedures reached this point, proceedings before royal justices became a forum for corporate thought and expression as to how the common law dealt with property disputes, including novel ones. There, in

31 C.H. McIlwain, Due Process of Law in Magna Carta, in 1 Selected Essays on Constitutional Law: The Nature of the Judicial Process in Constitutional Cases 174, 187 (Douglas B. Maggs ed., 1938).

32 Gaines Post, The Two Laws and the Statute of York, 29 Speculum 417, 429-31 (1954); Jean Dunbabin, Government, in Cambridge History, supra note 27, at 512.

33 Post, supra note 32, at 425-27; Lewis, supra note 21, at 470.

34 The classic example here is the jury, which Pollock and Maitland describe as a French royal prerogative; their claim has been challenged. Pollock \& Maitland, supra note 24, at 140-41.

${ }^{35}$ Hudson, supra note 23, at 19-21, 139-46. 
open court, English judges might act and speak on behalf of the community whose law they took up and applied.

Consider the development of writs. The basic story here is well-known. Writs are present in Anglo-Saxon government, but they are used largely for the purpose of confirming royal grants of land, and might be produced as a deed of title in a legal dispute. Under the Norman kings writs become more routine and formulaic; instead of being used as charters, they might directly "order [ redress of injustice by way of peremptory commands of reseisin or restitution," describing with particularity the matter at hand. ${ }^{36}$ By the late twelfth century, the popularity of these executive, police writs had produced a kind of "arms race," in which disputants each petitioned the king for relief, sending property back and forth, or in which an individual who anticipated being the target of a royal writ sought to preempt it by obtaining a writ exempting him from any subsequent writ. The effect of all this was to destabilize property because of the arbitrary character of royal interventions. Van Caenegem summarizes the state of affairs well:

\begin{abstract}
The English kings and their councilors also realized . . . that writs based on one-sided complaints led to contradiction and injustice and to the very disorder which they were supposed to combat. They were torn between quick, authoritative orders (with the danger of injustice) and full judicial proceedings (which could be too meticulous and slow). They found themselves faced with the old choice between jussio [order, command] and jurisdictio, and were learning that there was no short cut to justice. What was to be done? . . The only [workable] solution was to judicialize royal interventions, i.e. to surround them with the necessary judicial guarantees, to ensure fair examination of the merits of the case and the arguments and elements of proof involved. ${ }^{37}$
\end{abstract}

Thus under Henry II, judicial "original writs" take the place of executive writs. At first, judicial writs work by ordering barons to hold court themselves. For example, an early praecipe writ might order a baron to "do justice to" someone, or to do something "justly," and thus initiate process in a seigniorial or communal court. ${ }^{38}$ Later, we see writs that command a local justice or the sheriff to summon a jury to decide a matter. After royal justices begin to visit the countryside regularly, convening a court that was called the "general eyre," a writ might command that the petitioner be put in possession of the land in question, or the parties be summoned "before me or my justices." Still later, in the ostensurus quare writs, the language of command drops out entirely, and we are left simply with an instruction that the sheriff summon the parties to be before the royal justices regarding the matter described in the writ. ${ }^{39}$ By this time, the system of writs has become more rigid than the executive writs were; original writs are formulaic and issued as a matter of course by subordinate officials in the king's household (officials working for his secretary, or "chancellor"). ${ }^{40}$

\footnotetext{
${ }^{36}$ R.C. van Caenegem, The Birth of the English Common Law 34 (1973).

${ }^{37}$ Id. at 38-39.

${ }^{38}$ For example, the writ of right. Glanvill, supra note 26, bk. XII, \ 3.

39 John H. Langbein et al., History of the Common Law: The Development of Anglo-American Legal Institutions 87-92 (2009).

40 Pollock \& Maitland, supra note 24, at 150-51.
} 
Over a relatively short period of time, then, royal intervention in specific property disputes through the executive writ was transformed into a formulaic summons to a judicial proceeding. That proceeding was not always before royal justices, but increasingly it was, and pleading before royal justices quickly took on a considerable degree of formality and sophistication. The formality and sophistication of pleading before the royal courts was accompanied by the rise of specialists in those courts, both jurists (who replaced the great barons and high ranking ministers surrounding the king), and, several decades later, by professional advocates skilled in the art of pleading, "narrating" or "counting." 41 The Year Books show not only the sophistication (and cutting humor) of these professional lawyers, both on the bench and at the bar, but also reveal a relationship between pleading and the form of proof now available in royal courts, proof by country or, as we say, jury. Pleading was technical in part because of the need to narrow a dispute to a single matter to be submitted to the jury. The jury had to be constrained in this way because it comprised "fallible" human beings, in contrast to the older forms of proof based on divine revelation. ${ }^{42}$ Thus pleading by general denial, as in old forms of proof, was gradually displaced by special denial. A party pleaded to certain facts in order to pose a narrow factual question to the jury, which in turn required the judge to decide on the materiality of that question to the outcome of the suit. Thus the judge would rule, during pleading, whether such-and-such a defensive plea could succeed against such-and-such a form of action. ${ }^{43}$ The effect was to make substantive law. As the old phrase had it, substantive law was "secreted in the interstices of procedure," in oral conversation between judge and professional advocate on the viability of a particular plea under an original writ. Judge-made law in this sense occurred quite early in the development of the common law, and it needed neither written judicial decisions nor precedents nor a doctrine of stare decisis, all of which came later.

It is often noted that the professional lawyers who came to dominate royal courts were removed by their elite status and training from those they represented, as well as any alleged customary basis for the common law. We are to imagine, I think, the coif-wearing serjeants of the court of common pleas, who numbered fewer than 1000 in their 600 years of existence. These men, whose station was more lucrative than all but highest offices in the king's government, shared little in common with the Englishmen whose law they shaped, but much with each other. They lived together, were trained together, worked

41 John P. Dawson, A History of Lay Judges 129-33 (1960); J.H. Baker, An Introduction to English Legal History 155-58 (4th ed. 2007).

42 S.F.C. Milsom, Historical Foundations of the Common Law 42-43, 45-46 (2d ed. 1981).

${ }^{43}$ McSweeney, supra note 25, at 1151. Recently, Paul Brand has advanced a similar claim about royal justices at the opening of the Year Book period, at the end of the thirteenth century. Paul Brand, Judges and Juries in Civil Litigation in Later Medieval England: The Millon Thesis Reconsidered, 37 J. Legal Hist. 1, 27-40 (2016) ("[J]ustices were willing during this period to play an active role not just at the jury stage but also at the pleading stage of litigation. In a number of cases we find justices intervening in cases to ask questions of the parties and then on the basis of their answers giving judgment against them."). 
together, and must have shared values and understandings all their own. ${ }^{44}$ The law they made lost touch with local custom and, in some cases, served policies they judged worthy. ${ }^{45}$ The point is important, but I do not think it forecloses the position I am urging here. First, the learning of the professional lawyers was "common erudition," in that it was erudition in the law of the land, the law common throughout England in the royal courts. ${ }^{46}$ The law of the land was law for Englishmen insofar as they were Englishmen, not members of any particular, local community. If it was a law out of touch with the fabric of men's daily lives, that was in part by design, in part out of a necessity due to geographic scope. Second, if there was custom in play, then, it was not a body of usage with which the common lawyers were familiar and which they injected into the law, but a custom of treating the deliberative activity of the royal courts as constitutive of the common law. ${ }^{47}$ What made something count as the law of the land was its being "taken up" in this process, that is, being recognized as a reason guiding the resolution of a dispute. ${ }^{48}$ In this sense, the king's justices and the common lawyers maintained the common law for the Englishman, within the procedural framework established by the royal courts. They represented him there. Their office was to reason together in that setting about how best to resolve his disputes according to the law of the land. ${ }^{49}$

The regime of the early common law thus illustrates two important points. First, the early common law embodied a group of procedures whose effect was to regularize magisterial discretion. In the words of a leading commentator, an "element of developing common law ... was the exclusion or at least restriction of discretion. . . Royal administrators themselves displayed awareness of the distinction between royal arbitrariness and common law." 50 In this sense, common law procedures "helped to impose limits on the continuing personal elements in kingship." 51 Second, this regime was successful in part because it was acknowledged, or understood, as belonging to the realm. Those violently dispossessed of their land could obtain a remedy in the king's courts, and over time they came to regard the body of law applied in those courts as their birthright as subjects of

\footnotetext{
44 A.W.B. Simpson, The Common Law and Legal Theory, in Legal Theory and Legal History: Essays on the Common Law 380 (1987).

${ }^{45}$ Hudson, supra note 23, at 228-29.

${ }^{46}$ Cromartie, supra note 28 , at 11 ; Hudson, supra note 23 , at 230-31.

${ }^{47}$ Simpson, supra note 44 , at 376.

48 Brand, supra note 42, at 39 ("[W]e are dealing with a normative system . . which is created and developed through the cooperative effort of justices and lawyers, partly through rulings by the justices in specific cases . . . but also partly by the shifting professional consensus of lawyers and justices about what the law is."'); Gerald Postema, Classical Common Law Jurisprudence (Part I), 2 Oxford U. Commw. L.J. $155,166-67$ (2002).

49 Cromartie, supra note 28 , at 12.

${ }^{50}$ Hudson, supra note 23, at 233; Cromartie, supra note 28, at 17 . Cromartie dates this development later than Hudson.

${ }^{51}$ Hudson, supra note 23, at 233.
} 
the king. The law made by the king's judges became their law, not the exercise of an alien royal discretion.

\section{Judge-Made Law in the Early Republic}

We might be skeptical of finding anything like these understandings in the republican regimes of newly independent British North America. A distrust of lawyers and judges dependent on the Crown had been common in the colonies. ${ }^{52}$ After the Revolution, courts remained the primary point of contact between central government and citizen, and regularly bore the brunt of popular dissatisfaction with fluctuating state policies on matters of debt and taxation. Westerners shut down Massachusetts county courts during the winter of 1787-88 in what came to be known as "Shay's rebellion," demanding that they adjourn sine die and that their jurisdiction be transferred to Justices of the Peace, before whom proceedings would be more efficient and inexpensive. ${ }^{53}$ Anyone taking an oath should be free to practice law, and those who provided legal services to others for a fee should be limited in what they could charge. The Shaysites never achieved their program of legal reform, but the movement captures a strain of anti-lawyer, anti-common law utopianism familiar to students of American history. This sharpens the puzzle with which I began. How should we account for the constitutional elevation of the judiciary given a pervasive suspicion of trained lawyers and legalism?

It is worth noting that not all anti-lawyer utopianism targeted judicial discretion or judge-made law as such. The Shaysites, for example, were moved to take up arms principally by the costs of litigation and government in general; they regarded the county courts as a wasteful extravagance, and petitioned on the same grounds for elimination of the state Senate. ${ }^{54}$ Yet other, similar movements did attack the exercise of judicial discretion, and their arguments likely gave shape to the constitutional defenses of an independent judiciary that followed ${ }^{55}$ If independent judges were to make law, then that law had to be the product of appropriate institutional procedures (not just any procedures), and it had to be confined to appropriate topics. Thus the rise of the judiciary in the new republican regimes was accompanied by institutional reforms designed to meet criticisms of judicial discretion. We can see this best by examining the first major controversy over common-law jurisdiction in the early Republic, which concerned the common law of crimes.

\section{A. The Common Law of Crimes}

Federal jurisdiction over the common law was a result of legislative silence and the demands of the time. The Judiciary Act of 1789 had lodged jurisdiction over "all crimes

52 Lawrence Friedman, A History of American Law 53-59 (2005).

${ }^{53}$ Robert J. Taylor, Western Massachusetts in the Revolution 128-67 (1954).

${ }^{54}$ Id. at $134-35$.

55 John Phillip Reid, Controlling the Law: Legal Politics in Early National New Hampshire 96-102 (2004). 
cognizable under the authority of the United States" in federal circuit courts. ${ }^{56}$ Yet Congress said next to nothing about the procedures these courts should follow, ${ }^{57}$ and, crucially, passed only a skeletal crimes bill, criminalizing treason, forgery, rescue, and a variety of offenses related to the integrity of the judicial process. ${ }^{58} \mathrm{By}$ the time the bill passed, moreover, at the very end of April 1790, circuit courts were already in session. On April 14, two weeks earlier, the Circuit Court for the District of New York held a trial of two men on charges of "conspiracy to destroy a ship and murder the captain," an offense chargeable under "a nonstatutory maritime law of crimes." 59 Thus did federal courts begin to enforce an unwritten, customary law of nations. Early efforts along these lines apparently met with little objection. Perhaps unsurprisingly, then, when President George Washington proclaimed the United States' neutrality in the French Revolutionary Wars, he also declared it his intention to "cause prosecutions to be instituted against all persons, who shall, within the cognizance of the courts of the United States, violate the law of nations." ${ }^{60}$ The course had been suggested by Thomas Jefferson, then Washington's Secretary of State, who wrote to Attorney General Edmund Randolph that foreign war "brought into activity the laws of neutrality, as a part of the law of the land," which might serve as a basis for indictments. ${ }^{61}$ These indictments did cause controversy. After a jury acquitted mariner Gideon Henfield of such charges, the opposition press was jubilant. ${ }^{62}$

It is customary to treat the controversy over a federal common law of crimes as political and ideological, and in a sense it basically was. ${ }^{63}$ The French Revolution gave shape to an emerging party divide, and a federal common law of crime came to stand for that divide. Jeffersonian Republicans criticized the assertion of federal jurisdiction on grounds that it unlawfully expanded the powers of the national government at the expense of the states. ${ }^{64}$ But as others have noted, intersecting with these fears was a distinct concern about the judicial discretion implied by a common law of crime. ${ }^{65}$ One way of framing this concern is as part of a shift in views of the common law in general. Accord-

56 An Act to Establish the Judicial Courts of the United States, 1 Stat. 79 (Sept. 24, 1789).

571 Julius Goebel, Jr., History of the Supreme Court of the United States: Antecedents and Beginnings to 1801, at 608-11 (1971).

58 An Act for the Punishment of Certain Crimes against the United States, 1 Stat. 112 (Apr. 30, 1790).

59 William R. Casto, The Supreme Court in the Early Republic: The Chief Justiceships of John Jay and Oliver Ellsworth 130 (1995).

${ }^{60}$ By the President of the United States of America, A Proclamation (Apr. 22, 1793), in 1 Messages and Papers of the Presidents 149 (James Daniel Richardson ed., 1897).

${ }^{61}$ Letter from Thomas Jefferson to Edmund Randolph (Apr. 8, 1793), quoted in Goebel, supra note 58, at 624.

62 Trial of Gideon Henfield for Illegally Enlisting in a French Privateer, in Francis Wharton, State Trials of the United States During the Administrations of Washington and Adams 49, 88 (1849).

63 Lance Banning, The Jeffersonian Persuasion: Evolution of a Party Ideology 210-20 (1978); 1 Charles Warren, The Supreme Court in United States History 103-18 (1922).

${ }^{64}$ Casto, supra note 59 , at 156.

${ }^{65}$ Morton J. Horwitz, The Transformation of American Law, 1780-1860, at 10-11 (1977). 
ing to Morton Horwitz, who is most associated with this view, "it is plain that the specific attack upon common law crimes emerged from a distinctively post-revolutionary conviction that the common law was both uncertain and unpredictable." is that judges seem to flip back and forth between Horwitz's pre-and post-revolutionary "convictions." J7 Jefferson, too, at first approved of charging offenses under the law of nations, at least in maritime cases like Henfield, and then vigorously opposed prosecuting common-law misdemeanors. ${ }^{68}$ From considerations like these other commentators have concluded that the dispute was, perhaps, even more political than we had realized. ${ }^{69}$

I have no real objection to this line of thought, but it does pass over the particular branch of common-law jurisdiction invoked-misdemeanors — and this detail helps to make some sense of observed patterns of objection. Misdemeanors and similar breach-of-peace offenses figure heavily in the common-law prosecutions. Thus, according to the opinion of Attorney General Randolph, Henfield was "indictable at the common law, because his conduct comes within the description of disturbing the peace of the United States." ${ }^{70}$ In Henfield's case, that peace was underwritten by a treaty, but we see similar language in later cases involving domestic law. In United States $v$. Worrall, for example, where the defendant stood accused of having attempted to bribe the federal Commissioner of Revenue, District Judge Richard Peters stated that the "power to punish misdemeanors is . . . a common law power," which might be "enforced in a . . . judicial proceeding" to punish "an offence against the well-being of the United States." J1 Jurisdiction over the offense was, he thought, "essential to good government.,"72

Common law misdemeanors for breach of peace were distinguished by the breadth of discretion their execution implied. In his "system" of the laws of Connecticut, published in 1795, Zephaniah Swift explained that "it has been considered . . . impossible to designate every action, that deserves punishment," and that courts had therefore exercised jurisdiction over "all kinds of crimes of a public nature, all disturbances of the peace, and all other misdemeanors of notoriously evil example." ${ }^{73}$ Misdemeanors were, in this re-

66 Id. at 14.

${ }^{67}$ Stephen B. Presser, A Tale of Two Judges: Richard Peters, Samuel Chase, and the Broken Promise of Federalist Jurisprudence, 73 Nw. L. Rev. 26, 66-68 (1978).

${ }^{68}$ Casto, supra note 61, at 156. Once Jefferson became President, the government refused even to proceed with an ongoing prosecution of maritime crimes under the law of nations. Id. at 162.

${ }^{69}$ Presser, supra note 67, at 69. This seems to be Casto's view as well. Casto, supra note 61, at 156 ("Their real objection was to expanding the federal government's legislative jurisdiction.”).

70 Opinion on the case of Gideon Henfield, in 1 American State Papers 152 (Walter Lowrie \& Matthew St. Clair Clark eds., 1833) (emphasis added).

71 Trial of Robert Worrall for Attempting to Bribe a Commissioner of the Revenue, in Wharton, supra note 62, at 198.

72 Goebel, supra note 59, at 631. To be sure, another argument held that jurisdiction was implied by the statute creating the commissioner's office.

732 Zephaniah Swift, A System of the Laws of the State of Connecticut 365 (1795). Swift distinguished misdemeanors from "crimes expressly defined by statute or common law." Id. 
spect, closely related to the offenses against the "public police" and "oeconomy" described in Blackstone's Commentaries. ${ }^{74}$ Protecting the public peace could assume a preventive, forward-looking mode, by securing promises of good behavior from suspicious persons; and it entailed a significant discretion in the magistrate to identify threats in their varied costumes. ${ }^{75}$ These characteristics generated anxiety about misdemeanors and police jurisdiction. Swift, writing just as the controversy over the federal common law of crimes had generated momentum, urged even the state courts of Connecticut "to exercise such power with great circumspection and caution." ${ }^{, 76}$ He was concerned about a lack of notice to the accused. From another perspective, the power was not properly judicial at all. Years earlier, a young Thomas Jefferson had noted in his legal commonplace book that the power of the King's Bench to "correct . . . misdemeanors extrajudicial, tending to breach of peace," allowed for "redress . . . by due course of law.",77 Breach of peace, Jefferson had thought, was extrajudicial, although the common law might provide redress. It was primarily this jurisdiction that took on a partisan appearance in the $1790 \mathrm{~s}^{78}$ If that appearance followed, even just in part, from the arbitrary discretion involved, then a constitutional answer to the controversy necessitated an account of the discretion fit for judges in a republic.

\section{B. Judge-Made Law After the Common Law of Crimes}

Following the controversy over federal common-law misdemeanors are two further developments with which it seems natural to draw a connection. First, state legislatures began to assert control over police jurisdiction. Although courts continued to employ the doctrine of public nuisance to similar ends, significant portions of the quasiregulatory, quasi-legislative police jurisdiction became police power. ${ }^{79}$ Second, leading jurists developed accounts of government and legal rights that justified legislative police power and articulated the place of courts relative to legislative power. ${ }^{80}$ The flowering of legal treatises distinctive of this period was in part an effort to mount persuasive constitu-

\footnotetext{
744 William Blackstone, Commentaries on the Laws of England 106-15 (Ruth Paley ed., 2016) (1769); F.M. Dodsworth, The Idea of Police in Eighteenth Century England: Discipline, Reformation, Superintendence, c.1780-1800, 69 J. Hist. Ideas 583, 589-90 (2008).

75 Blackstone, supra note 74, at 166-70; Markus Dirk Dubber, The Police Power: Patriarchy and the Foundations of American Government 50-59, 93 (2005).

${ }^{76}$ Swift, supra note 73 , at 365 .

${ }_{77}$ Legal Commonplace Book, No. 245, quoted in David Thomas Konig, Legal Fiction and the Rule(s) of Law: The Jeffersonian Critique of Common-Law Adjudication, in The Many Legalities of Early America 97, 108 (Christopher L. Tomlins \& Bruce H. Mann eds., 2001).

${ }^{78}$ Kathryn Preyer, Jurisdiction to Punish: Federal Authority, Federalism, and the Common Law of Crimes in the Early Republic, 4 Law \& Hist. Rev. 223, 263-64 (1986).

${ }^{79}$ Dubber, supra note 75 , at 95 .

${ }^{80}$ Novak, supra note 6 , at 86-103.
} 
tional arguments for independent, judge-made law in a republic. ${ }^{81}$ That its writers were only partly successful is shown by the codification movement, which began in the following decades. ${ }^{82}$

Arguments in treatises proceeded along a number of different tracks. ${ }^{83}$ For some jurists, a key move seems to have been distinguishing judicial discretion from prudential discretion, a distinction that turned on the special procedures that characterized commonlaw courts. John Marshall put the idea in a speech on the floor of the House of Representatives in 1800: "[T] o come within this description [within the "Judicial Power" vested by Article III of the federal Constitution], a question must assume a legal form, for forensic litigation, and judicial decision." The power to resolve such cases, said Marshall, "had never been understood to confer . . . any political power whatsoever." ${ }^{\text {" A }}$ As it happened, Marshall was employing these ideas to describe limits on judicial power, in order to defend President John Adams from criticisms of usurping it; but the "forensic" character of judicial procedure could also be used to defend claims of judicial power.

We find such an account in James Kent's Commentaries on American Law. ${ }^{85}$ Kent defined the common law as those "principles, usages, and rules of action . . . which do not rest for their authority upon any express or positive declaration of the will of the legislature." The "best evidence" of these principles, usages and rules of action, wrote Kent, "is to be found in the decisions of the courts of justice . . and in the treatises and digests of learned men." ${ }^{86}$ Why? Judicial decisions evidenced the common law because of what Kent called the solemnity of a judicial proceeding. "A solemn decision upon a point of law, arising in any given case, becomes an authority in a like case, because it is the highest evidence which we can have of the law applicable to the subject." What made a decision solemn, in turn, was a solemn course of proceedings: "If a decision has been made upon solemn argument and mature deliberation, the presumption is in favour of its correctness, and the community have a right to regard it as a just declaration or exposition of the law." ${ }^{, 7}$ Thus Kent connected the formality of judicial proceedings with the court's expository function. In order for the court to express the law, including novel law, it had to come to that law after a course of deliberative argument between the parties, conducted under the

81 3-4 G. Edward White, History of the Supreme Court of the United States: The Marshall Court and Cultural Change, 1815-35, at 80 (1988). White is describing a body of literature whose boundaries fall outside the time period in his title, starting with St. George Tucker's edition of Blackstone's Commentaries, which Tucker wrote in the 1790 s.

82 On the connection between treatises and the codification movement, see Langbein et al., supra note 40, at 851.

${ }^{83}$ Many of these writers were anti-Blackstonian, but within this group there were significant distinctions; we could distinguish, for example, anti-deductivists and anti-positivists. Novak, supra note 6, at 63-66; Michael Lobban, The Common Law and English Jurisprudence, 1760-1850, at 56-79 (1991).

844 The Papers of John Marshall 95-96 (Charles T. Cullen \& Leslie Tobias eds., 1984).

851 James Kent, Commentaries on American Law 439 (1826).

86 Id. at 440.

${ }^{87}$ Id. at 441-42. 
strictures of common-law procedure. The process was necessary because it gave shape to what Kent elsewhere called the "legal discretion" of the judge. ${ }^{88}$ Legal discretion was not a power to choose according to one's private interest, but a capacity of judgment informed by the reason of the community that emerged in the course of the proceeding. ${ }^{89}$ It was a social capacity, not a private one.

Of course, legal discretion did imply some choice. ${ }^{90}$ Its exercise did not make for a form of decision-making immune to dispute. It implied the use of trained judgment to select relevant authorities and characterize them. ${ }^{91}$ This was a matter over which there might be considerable divergence and disagreement. The value of judicial procedure for Kent, then, was not that it foreclosed the possibility of objection to the court's decision; rather, its value was its use as a device for expressing and giving effect to the particular reason of the community - to what that community recognized as grounds for action. The acts of the legislature, in contrast, were subject to the forces of factional politics, and often expressed the private interest of the dominant faction rather than the community. "Courts of justice," wrote Kent, "are organized with peculiar advantages to exempt them from the . . baneful influence of faction." 92 Years later, Marshall marked out much the same distinction, describing the common law as "human reason applied by courts, not capriciously, but in a regular train of decisions, to human affairs, according to the circumstances of the nation, the necessity of the times, and the general state of things." 93

This collection of views about the common law and the form of judicial proceedings is relevant to our topic for two reasons. First, it shows the central place that procedure held in the view of leading jurists of the early Republic. Courts of justice were set apart from the other institutions of government by the nature of their proceedings. Second, those proceedings help to define the parameters of judicial power under a republican form of government. A judge in a republic could have no authority to impose his will on the people. The common law therefore had to be something other than a series of legislative acts, assuming one thought of legislation as an exercise of arbitrary discretion. By emphasizing the forensic character of litigation, or the solemnity of the judicial pro-

88 James Kent, Introductory Lecture to a Course of Law Lectures (1794), in 2 American Political Writing in the Founding Era, 1760-1805, at 942 (Charles S. Hyneman \& Donald S. Lutz eds., 1983).

89 Coke described a contrast between legal discretion and "private affections" in Rooke's Case: " $[\mathrm{N}]$ otwithstanding the words of the commission give authority to the commissioners to do according to their discretions, yet their proceedings ought to be limited and bound with the rule of reason and Law. For discretion is a science or understanding to discern between falsity and truth . . . not to do according to their wills and private affections." Rooke’s Case, 5 Co. Rep. 99, 100 (1598).

${ }^{0}$ Cf. H. Jefferson Powell, The Political Grammar of Early Constitutional Law, 71 N.C. L. Rev. 949, 100608 (1993).

${ }^{91}$ Charles Hobson, The Great Chief Justice: John Marshall and the Rule of Law 35 (1996); Kent, supra note 87 , at 445 ("The exercise of sound judgment is as necessary in the use, as diligence and learning are requisite in the pursuit, of adjudged cases.”).

92 Kent, supra note 90 , at 941-42.

${ }^{93}$ Livingston v. Jefferson, 15 F. Cas. 660 (C.C.D. Va. 1811). 
ceeding, one could understand a court of law as creatively explaining or unpacking what the law of the community was and had to be with respect to a dispute. ${ }^{94}$ The court was not simply declaring existing customary law. It was making novel law-but novel law for the community whose court it was. In contrast, arbitrary discretion, whether exercised by a governor or by a legislature, served private ends.

Even if one accepts the account of proceduralism I am offering, one might object to my effort to foist it onto James Kent, whose jurisprudence is not uncommonly described in very different terms. In the same essay cited above, Morton Horwitz grouped Kent with what he called the "instrumentalist" judges of the early nineteenth century, especially after his appointment as New York's Chancellor, where Kent professed to be writing on a blank slate and to be free to describe principles "suited to my view of the case." "Wh Whether or not one accepts Horwitz's larger thesis, nothing in the brief account offered here should be taken to imply the view that Kent thought a court of law an inappropriate venue for legal change. His Commentaries do contain a theory of stare decisis, but that theory is not absolute. It gives due regard to the values of stability and notice. It shows a concern with the very argument set out in Part II, above. As Kent puts it, "If judicial decisions were to be lightly disregarded, we should disturb and unsettle the great landmarks of property. ... [W] [hen a rule has been once deliberately adopted and declared, it ought not to be disturbed . . . except for very cogent reasons; and it the practice were otherwise, it would be leaving us in a state of perplexing uncertainty as to the law." ${ }^{, 96}$ In Kent's view, stare decisis strengthens the common law's claim to being a body of fixed, known rules. Yet stare decisis cannot be an absolute doctrine, because circumstances change: "The great difficulty as to cases, consists in making an accurate application of the general principle contained in them to new cases, presenting a change of circumstances." 97 Communities themselves change, and courts must respond to these changes if they are to retain their role as expressing the law for that community. As Kent describes it,

Considering the influence of manners upon law, and the force of opinion, which is silently and almost insensibly controlling the course of business and the practice of the courts, it is impossible that the fabric of our jurisprudence should not exbibit deep traces of the progress of society, as well as the footsteps of time. The modern reports . . are . . accompanied by illustrations best adapted to the inquisitive and cultivated reason of the present age. But the old reporters cannot be entirely neglected ....98

The terms of the dispute are quite different, but it is possible to see, I think, that at least some eighteenth-century Americans thought of judge-made law in terms that

94 Matthew Steilen, Judicial Review and Non-Enforcement at the Founding, 17 U. Pa. J. Const. L. 479, 539 (2014).

95 Horwitz, supra note 65, at 124-26. Horwitz's thesis has come under criticism on several fronts. Peter Karstein, Heart Versus Head: Judge-Made Law in Nineteenth-Century America 33-35 (1997); A.W.B. Simpson, The Horwitz Thesis and the History of Contracts, in Simpson, supra note 46, at 203, 208-12.

${ }^{96}$ Kent, supra note 85 , at 443 .

97 Id. at 445.

${ }^{98}$ Id. at 445-46 (emphasis added). 
would render it consistent with a government of laws. Law made in the decision of a case on solemn proceedings - law made in forensic litigation-was not the exercise of arbitrary discretion that legislation was then fast becoming. Despite constitutional framers' best efforts, legislation might be bent toward private interest, and in this respect inconsistent with basic human freedom. Executive discretion might be distorted by the same forces of factional politics. For a certain stripe of American lawyers, the court of law was a point of contrast, an anodyne, and an anchor for a government of laws. Proceedings in the court were slow, solemn, forensic, and public. They appeared to be guided by something other than, or more than, factional interests. Each case invited the community to acknowledge, or repudiate, the principles announced by an earlier court. In this peculiar way, the institutional setting made it possible for a community in court to freely give the law to itself - to speak the law, which is "the way a community communicates with itself about itself." "99 For those who saw judicial proceedings in such a light, this was the core of a constitutional argument that judge-made law was essential to republican government and that properly constituted courts of law were of vital importance to the maintenance of republican regimes.

${ }^{99}$ Laurence Claus, Law's Evolution and Human Understanding 98 (2012). 